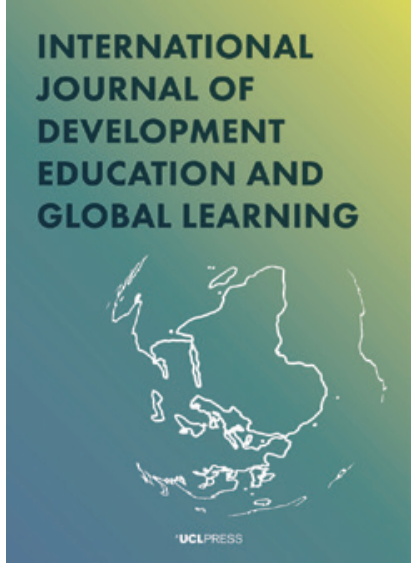

${ }^{ \pm}$UCLPRESS

\section{INTERNATIONAL JOURNAL OF DEVELOPMENT EDUCATION AND GLOBAL LEARNING}

e-ISSN: $1756-5278$

Journal homepage:

https://www.uclpress.co.uk/pages/international-journalof-development-education-and-global-learning

\title{
Planting the seeds of perspective consciousness: Creating resource sets to inspire compassionate global citizens
}

Sheila Baker(D) and Debby Shulsky ii

\section{How to cite this article}

Baker, S. and Shulsky, D. (2020) 'Planting the seeds of perspective consciousness: Creating resource sets to inspire compassionate global citizens'. International Journal of Development Education and Global Learning, 12 (1): 4-20. https://doi.org/10.14324/ IJDEGL.12.1.02

Submission date: 21 December 2018

Acceptance date: 14 October 2019

Publication date: 30 June 2020

\section{Peer review}

This article has been peer-reviewed through the journal's standard double-blind peer review, where both the reviewers and authors are anonymized during review.

\section{Copyright}

(C) 2020 Baker and Shulsky. This is an Open Access article distributed under the terms of the Creative Commons Attribution Licence, which permits unrestricted use, distribution, and reproduction in any medium, provided the original author and source are credited.

\section{Open access}

International Journal of Development Education and Global Learning is a peer-reviewed openaccess journal. 


\title{
Planting the seeds of perspective consciousness: Creating resource sets to inspire compassionate global citizens
}

\author{
Sheila Baker* and Debby Shulsky* - University of Houston-Clear Lake, USA
}

\begin{abstract}
What skills are needed to view the world beyond one's immediate reality? A deep perspective consciousness is required to live and solve complex issues within a globalized context. Cultivating the seeds of perspective consciousness roots the growth of an open-minded, humanly connected, problem-solving citizen. Literature is positioned as a powerful catalyst for the expansion of perspective, acceptance of varied lived experiences and discovery of connections between ourselves and others far removed from our reality. Educators are placed in powerful roles in which they can, with great intentionality, sow a garden of books which meaningfully expands the perspectives of citizens. The book collections, recommendations and strategies presented in this article serve as seeding packets that deeply root perspective consciousness within all learners.
\end{abstract}

Keywords: perspective consciousness, global citizenship, children's literature, book collections

\section{Introduction}

As I sat in front of the computer in my home office lamenting the lack of internet access, my son said, 'Sounds like a first-world problem to me, Mom.' In that moment, I was snapped from my egocentric perspective into an immediate and humble consciousness that viewed the situation from a different perspective. Usually - 98 per cent of the time - I have the internet at my fingertips for no other reason than my geographic and economic privilege. My wise teenager reminded me that, for others, both in my own country and beyond its borders, my problem was actually not a problem at all.

We all live in our own worlds. We can easily forget the humanity around us and the glaring difference of our reality to that of others. Broadening our consciousness to see past our 'first-world problems' moves beyond mere gratitude and fosters compassion for those around us. In this way, we can expand our capacity for acceptance, altruism and empathy. In a world where borders are becoming invisible and globalization is the current paradigm, considering the perspective of others is imperative.

Traditionally, educators have been at the forefront of expanding learners' knowledge and thinking. We suggest that the role of the educator is deepened to include the skill of facilitating a panoramic perspective of the world for learners in their classrooms. This expansive view requires an intentional development of a perspective consciousness, as defined by Hanvey (1982: 162):

The recognition or awareness on the part of the individual that he or she has a view of the world that is not universally shared, that this view of 
the world has been and continues to be shaped by influences that often escape conscious detection, and that others have views of the world that are profoundly different from one's own.

In other words, perspective consciousness is being awakened to one's own unique perspective and its limitations. Broadening our perspective and increasing our knowledge of that of others is a fluid endeavour and enables learners to embrace the experiences and ideas of others. If this is the goal, the question then becomes: How can educators bring this quest to fruition?

Literature is positioned as a powerful catalyst for the expansion of perspective, acceptance of varied lived experiences and discovery of connections between ourselves and those removed from our reality. Rochman (1993: 9) asserts, 'The best books break down borders. They surprise us - whether they are set close to home or abroad. They change our view of ourselves; they extend that phrase "like me" to include what was foreign and strange.' Many teachers look to their classroom collection of books when seeking ways to engage learners. Historically, books have been the epicentre of expanding the imagination, curiosity and understanding of the world for readers young and older. In the current educational landscape, teachers often face challenges regarding the time and expertise that are needed to select rich and relevant texts for their classrooms. This article presents book collections with an intentional focus on the development of perspective consciousness. The goal of the collections offered moves beyond mere perspective identification for learners and encourages continuous development of the disposition of perspective consciousness. We believe that teachers and school librarians can generate year-round instructional activities and seek culturally relevant and challenging resources to seed the development of perspective consciousness within their learning communities. Simultaneously, teachers and librarian educators must ensure the inclusion of experiences within their courses that promote the exploration and expand the understanding of perspective consciousness that will consequentially influence their students' future practice. To support educators in this charge, this article offers themed resource sets to inspire the systematic cultivation of perspective consciousness - a foundational attribute of a global citizen.

\section{Literature review}

\section{Global citizenship education}

Our current work focuses on the idea of cultivating the dispositions required of a global citizen (Shulsky et al., 2017; Shulsky and Hendrix, 2016). Through this exploration, we have concluded that defining global citizenship and its supporting ideals is a far from straightforward endeavour. The body of literature regarding citizenship roles within the globalized context ranges in interpretation (Banks, 2008; Bista and Saleh, 2014; Bosniak, 2001; Caruana, 2014; Clifford and Montgomery, 2014; Eidoo et al., 2011; Karlberg, 2008; Scott Belt, 2016). The challenge of articulating what a global citizen is, complicates educational approaches in its cultivation. Most commonly, and with levels of variation, global citizenship education (GCE) is an avenue to the development of global mindedness. UNESCO (2019: 1) states, 'Global Citizenship Education aims to empower learners to assume active roles to face and resolve global challenges and to become proactive contributors to a more peaceful, tolerant, inclusive and secure world.' Myers (2016: 4) attests to the layered aspects of GCE as removed from mere civics education and expanded to global contexts when he contends: 


\begin{abstract}
A better model for understanding GCE is a web of interconnected and intersecting experiences as individuals become aware of the ways that political issues and actors shape the local, familiar world around them. Thus, teaching youth to understand how to engage with the world can hardly 'stop at the border,' whether a real or imagined border at a local, regional or national scale.
\end{abstract}

We understand that, contextually, the concept of globalization itself is highly debated as nationalist movements become more popular around the globe. This state of affairs highlights the complexity of the twenty-first century, where borders are fading due to technological advancements. In such a world, the reality is that we, as citizens of our individual nations, do have a stake in the actions and reactions of others. It is this reality that holds global citizenship education as an imperative to prevent myopic views of the world. Regardless of pedagogical philosophy, educators need to address the everchanging nature of citizenship in a globalized world.

\title{
Perspective consciousness
}

Perspective consciousness in its simplest form is the realization that the reality of others is not the same as ours. Being awakened to the fact that not all hold our view of the world is at the heart of a global community that looks beyond constructed geographical borders. Without an awakening of perspective consciousness, one's egocentric lens will create a barrier between the 'other' and us. This distance leads to the introversion of thought in ways that inhibit the development of essential dispositions in a global society. Shulsky and Hendrix (2016: 103) view perspective consciousness as the epicentre of the development of the following habits of mind for global citizenship: (1) broadmindedness - 'the willingness to see and hear ideas removed from one's personal paradigm'; (2) innate contemplation - 'deep reflection as a natural, initial instinct'; and (3) critical conviction - 'deep-seated belief that one is open to analytical exploration and possible evolution'.

The narratives that make up our outlook on the world are, on the surface, constructed by our nationality, culture, religion, social status, age and gender (Burnouf, 2004). Perspective consciousness unearths aspects of perspective that are concealed below the surface of these seemingly transparent characteristics. Our views can be blatantly or covertly biased, prejudicial and/or stereotypical (Bell et al., 2015). Consequently, the cultivation of perspective consciousness is an imperative in the charge of developing global-minded members of society who possess ways of being that resist prejudice, challenge stereotypes and embody empathy.

\section{Standards and impact}

In the era of the new American Association of School Librarian (AASL, 2018) standards, diverse perspectives in the context of globalization are prominent throughout the document. This challenges teachers, librarians and educators in preparation programmes to consider meaningful practices and rich activities that promote both teachers' and learners' expansion of perspective. In consonance with the AASL, the National Standards for the Preparation of Social Studies Teachers charge teachers and teacher educators with the promotion of civic dispositions and competences, and with preparing learners to be 'informed advocates for an inclusive and equitable society' (NCSS, 2017: 25). Additionally, the International Society for Technology in Education (ISTE, 2020) updated their Standards for Students to recognize the need to broaden perspectives and collaborate with others around the world. The work of these 
organizations and others echo the nearly two-decades long mission of the Partnership for 21st Century Learning (P21, 2014), the current iteration of the Partnership for 21st Century Skills. The following is asserted within the organization's Global Education Framework:

P21 believes that students should develop the attitudes, skills, and knowledge to understand and participate in a globally connected world. This includes the capacity to:

- Explore their own cultures, make comparisons with other cultures and investigate global issues and challenges.

- Improve their critical thinking, problem solving, perspective taking, and research skills.

- Develop awareness of cultural diversity and global issues. (P21, 2014: 1)

Building from this foundation, P21's (2014: 2) Global Education Framework provides a series of essential elements and actions which support teachers in reaching levels of global competence that will enhance students' preparation for college, careers and life. This mission directly correlates with the new National Standards for the Preparation of Social Studies Teachers as evidenced in Standard 5 - Professional responsibility and informed action, which states:

Candidates reflect and expand upon their social studies knowledge, inquiry skills, and civic dispositions to advance social justice and promote human rights through informed action in schools and/or communities.

(NCSS, 2017: 25)

More specifically, Element $5 b$ articulates:

Candidates explore, interrogate, and reflect upon their own cultural frames to attend issues of equity, diversity, access, power, human rights, and social justice within their schools and/or communities. (NCSS, 2017: 25)

A clear pattern of the intentional development of a global perspective is present within multiple professional standards across educational disciplines. These standards support the premise of this article - that the development of perspective consciousness is an imperative habit of mind in a global citizen.

\section{Seeding resource sets}

Instructional leaders, including teachers, librarians and educators, in preparation programmes are curators of resources and hold an impactful position that enables them to facilitate the development of perspective consciousness in varied educational contexts. Seeding this disposition is foundational in cultivating learners' discovery of others' lived experiences and comparative realities - a way of being required of a global-minded citizen.

Table 1 presents themes and titles to inspire the curation of resource sets positioned to seed the development of perspective consciousness and more expansive views of the world. We present the titles as a starting point of innovation in the curation of book collections aligned with the development of empathetic, compassionate and broad-minded human beings. The hope is that these titles spark discussion and innovative thought when deciding how to select and share books that awaken learners to the realities of a world beyond their own. 


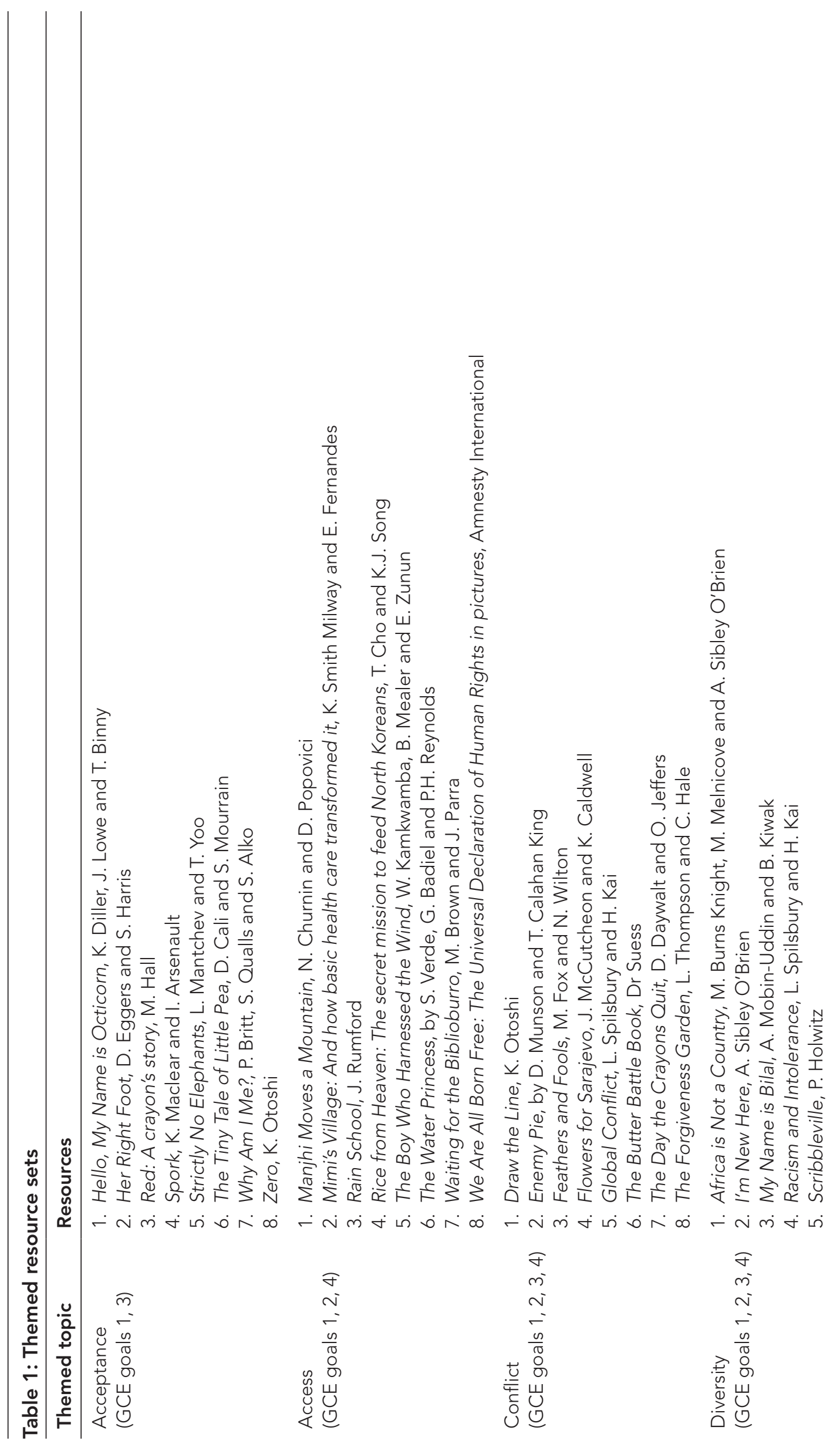




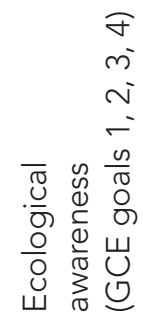

\section{mi} $\stackrel{2}{\check{2}}$

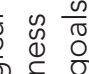
बे

西

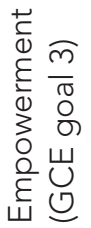
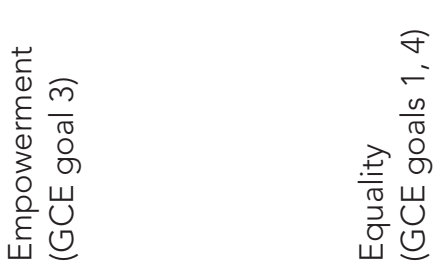


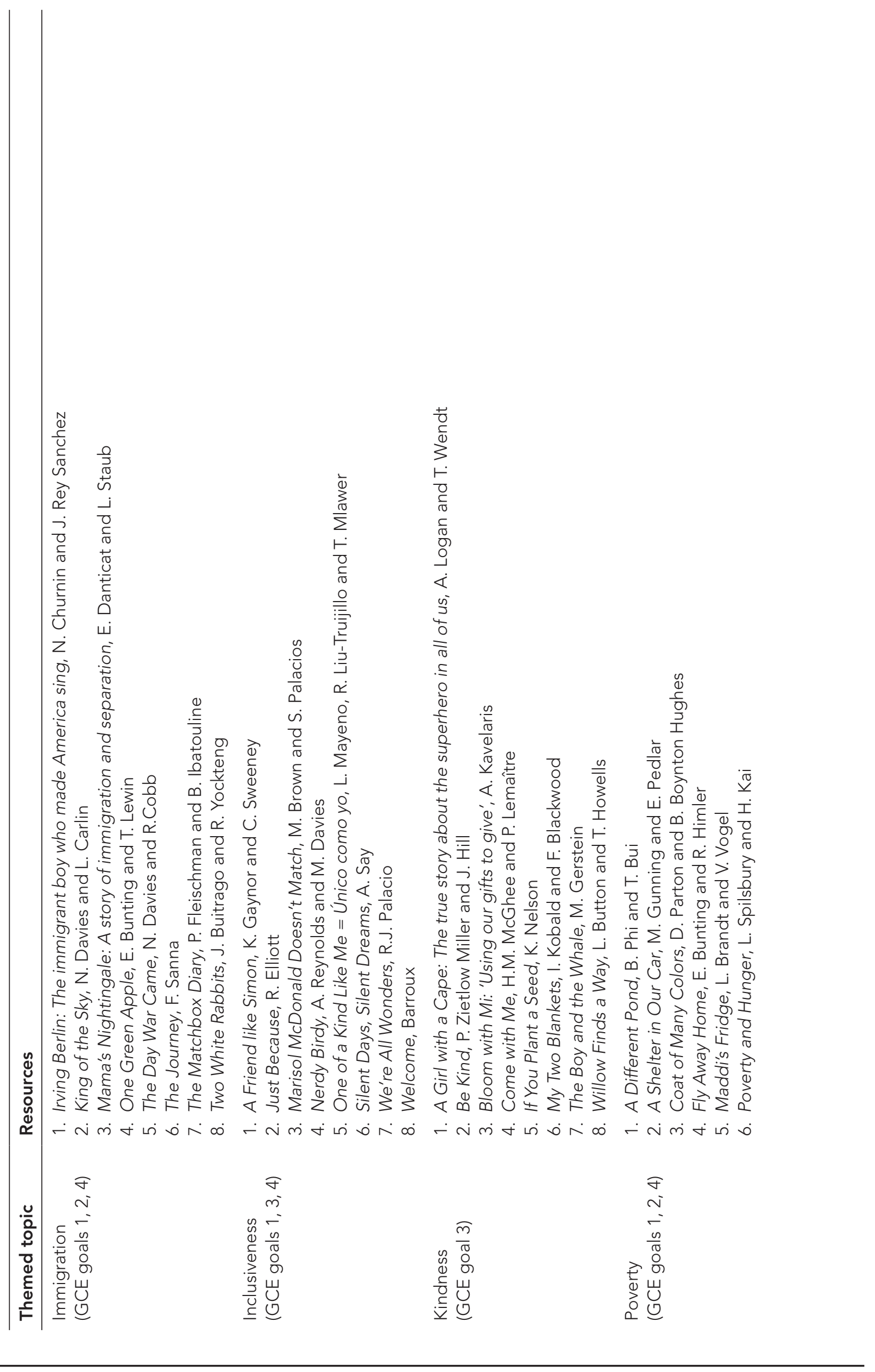




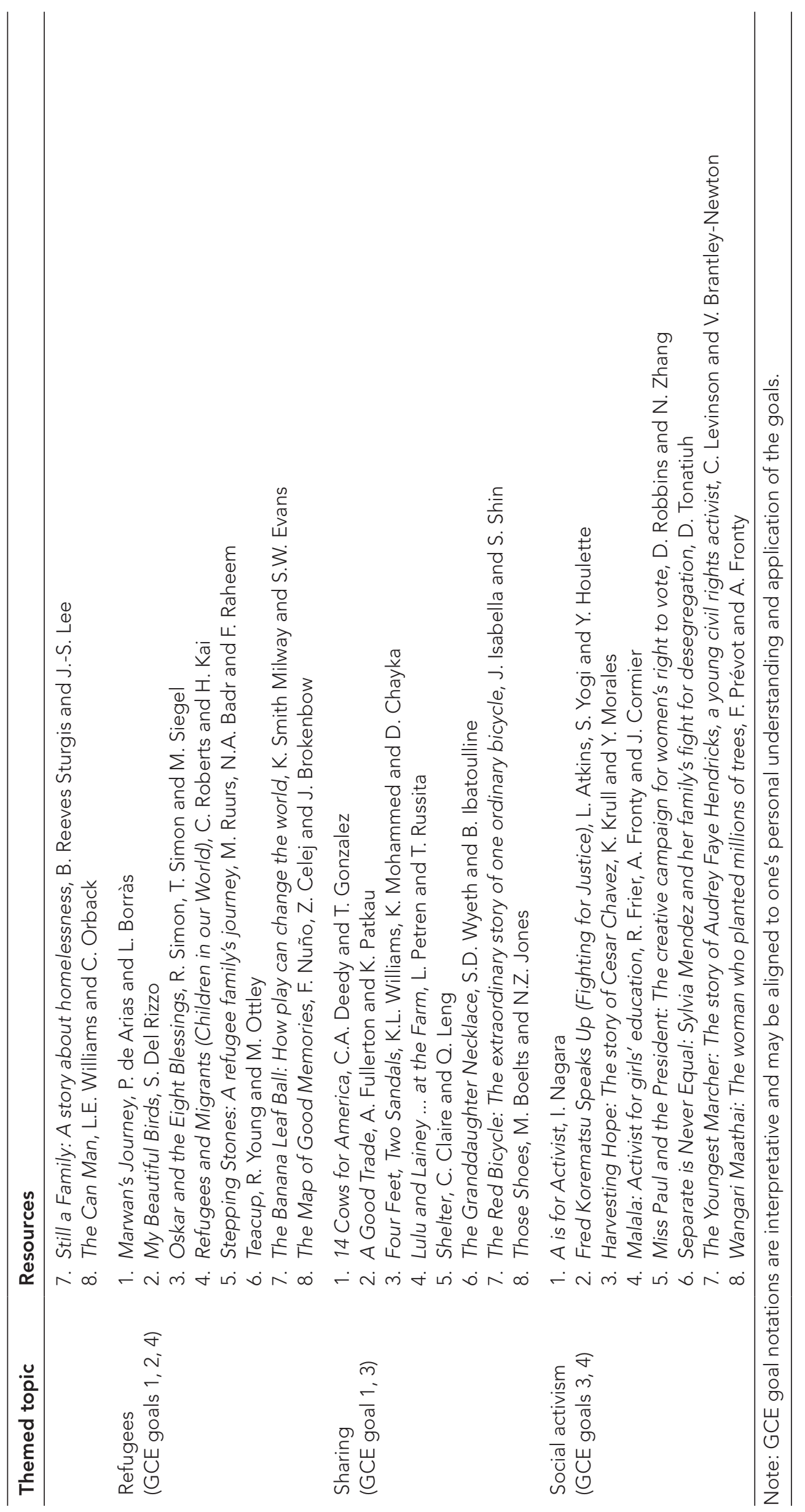


As any educator well knows, there is often an endless list of books from which to develop special collections. This was true as we curated the books highlighted in this article. Our organizational system was based on broad categories of thought by which learners can begin to shift their view of the world in humble ways that seed actions to make a difference in their immediate world and beyond. The books within this list are aligned with the common goals of global citizenship education, as articulated by UNESCO (2019). The goals of a global education include:

1. an understanding of the interconnectedness with others from around the globe;

2. an increased knowledge of how economies, cultures, environments, governments, and geography impact all citizens;

3. the cultivation of the skills, attitudes, and values that promote collaboration and empowered action to change on both an individual and collective level; and

4. the actions that develop a socially just and sustainable world. (Castle, 2014)

The categorization of the titles in Table 1 have noted correlations (GCE goal 1, GCE goal 2, etc.) to UNESCO's global citizenship education goals. These themes are unbounded and the books can be categorized in a multitude of ways. In addition, readers should note the purposeful absence of age/grade levels for the books presented. This conscious choice aligns with our contention that picture books can be used with learners of any age, even adults, to engage them in age-appropriate critical discussions and activities about meaningful topics. At the very least, these books will empower readers to give thought to a new world view.

\section{Perspective consciousness and mindfulness}

We contend that development of mindfulness in learners intertwines with the formation of perspective consciousness. Recently, a range of titles has been written on mindfulness. Most of these titles focus on the practice of promoting an awareness of feelings, access to calmness and conscious reaction. In a study by Cardaciotto et al. (2008), the Philadelphia Mindfulness Scale assessed present-moment awareness and acceptance. Books with this focus build the foundation for both inner and outer awareness - a foundational component of a rich perspective consciousness. As such, we recommend that educators include titles specifically focused on mindfulness. A World of Pausabilities (Sileo and Zivoin, 2017) and Silence (Lemniscates, 2012) are offered as inspirational starter books that will help to develop a reciprocal scaffolded curriculum that will awaken learners' consciousness to themselves and the world around them.

\section{Considerations for book selection}

Expertise in the selection of books for collections varies, depending on the educational roles of those undertaking this task. Librarians are experts in implementing selection criteria and, in this respect, are valuable partners to teachers. Teachers, on the other hand, may possess limited knowledge regarding the thoughtful curation of special book collections. No matter the level of expertise, foundational processes should be employed when selecting books for focused book collections. As book collections are put together, the following American Library Association's (ALA, 2018) baseline criteria should be considered and used in the selection, analysis and curation of resources:

- Does the collection support and/or enrich the curriculum?

- Does the collection support and/or enrich learners' interests and learning?

- Are the books, texts and/or illustrations of high quality?

- Are the books appropriate for the learner? 
- Do the books contain accurate, authentic, factual information?

- Have the books earned positive reviews and recommendations?

- Are the books of high interest to the learners?

- Does the collection offer differing viewpoints on controversial issues?

- Do the books provide a global perspective?

- Do the books promote diversity through the characters, authors, and illustrators?

- Does the collection include both print and digital formats?

- Is the durability of the books suitable for the audience?

- Are the books within the collection cost-effective?

- Does the collection mirror the population of learners?

This list provides a solid foundation for curating a book collection; however, it seems to have a limited focus on diversity and global perspective. We suggest extending these selection criteria with an intentional focus on the development of perspective consciousness. The extension of such criteria requires a more narrow approach, one guided by critical analysis. As selections are made, emphasis should be placed upon the mindful engagement of learners' hearts in regard to humanity. The following list of prompts offers a starting point for such a fine-tuned selection process:

- Are multiple perspectives regarding shared human experiences represented?

- Does the book expand or shift the learners' lens of themselves and/or that of others?

- Is there potential to build an understanding and acceptance of others' lived experiences?

- Does the book expose readers to the ideals of empathy, compassion and openmindedness?

- Does the book inspire readers to step into the role of a compassionate global citizen?

\section{Nurturing ways: Learner activities}

It is not enough just to have a thoughtfully selected book on the classroom bookshelf. The power of literature, beyond the words on the page, relies on the activities and meaningful inquiry inspired by those words. To this end, we offer springboard activities that can extend the concept of perspective consciousness as well as many other admirable dispositions and traits required of open-eyed citizens. Educators are encouraged to use these activities in partnership with the suggested literature and other relevant books within their own educational context.

\section{Close-up lens}

Zoom in on an image in the book and facilitate a focused discussion on the similarities and differences of the portrayed experiences to encourage learners to view and think about the perspectives of others. Possible questions that promote perspective consciousness, as adapted from Wiggins and McTighe (2005), may include:

- What does the image tell us about the experience or character?

- How is the image like something in your life?

- How is the character like you?

- What would you like to know about this image?

- What would you like to ask of those in this image? 
- What different points of view are present in the image?

- How does the story told by the image connect to your life?

- How could the image be viewed or understood from another's perspective?

- How is the story/image different from your own experience?

- Place yourself in the image. What do you think you would experience?

- How is what is illustrated in the image different from your own experience?

\section{Question formulation technique (QFT)}

This technique cultivates learners' ability to pose and formulate questions about what they are learning and the world around them. Self-generated questions encourage learners to move beyond superficial treatment and acceptance of knowledge, experience and interactions with others. As presented by Rothstein and Santana (2011), the QFT follows these steps:

1. Educators select a question focus (Qfocus). It may be an image, quote, artefact, song, etc.

2. Present Qfocus to learners.

3. Learners generate their own questions following these rules:

a. Ask as many questions as you can, without judgement or discussion.

b. Do not answer the questions.

c. Write down every question exactly as stated.

d. Pose statements as questions.

4. Learners identify different types of questions (open-ended, close-ended) and transform questions (e.g. transform a select number of open-ended to closed; close-ended to open).

5. Learners prioritize questions.

Once a classroom list of questions is generated, the educator can use them as inspiration for a variety of activities, i.e. personalized research; compelling, inquirybased explorations and as catalysts for high-interest, student-inspired classroom lessons.

\section{D perspective role play}

This activity positions learners as characters or inanimate objects within a book. Learners are guided through the process as follows:

1. Project an image from the book.

2. Discuss the perspectives shown in the image.

3. Distribute thought-bubble templates to learners, who then compose a perspective position on their thought bubble for any selected character or object. For example, given an image of Christopher Columbus and his men in discussion with people of First Nations, learners write a script of the conversation between the characters. The boat in the foreground or the clouds could show an alternative perspective to the scene beyond what the characters would share.

4. Randomly select learners to stand in front of the image with their thought bubbles, creating a living discussion from a variety of perspectives.

\section{Five senses poetry}

Writing poetry is often challenging for learners. This strategy softens the challenge by merging poetry and perspective exploration through the following steps: 
1. Set the purpose for listening/viewing as being aware of the emotions stirred by the experience.

2. Read a book aloud or share an image with the learners.

3. After reading/viewing, learners remain silent and identify the emotions that surfaced.

4. Generate a class list of learners' emotions.

5. Ask learners to choose an emotion (which can be from the list or not). State the emotion as a title and equate it with the following:
a. Colour
b. Taste
c. Smell
d. Touch
e. Sound.

For example:

Happiness -

is bright yellow.

tastes like lemon gelato.

smells like suntan lotion.

feels like the softest of blankets.

sounds like the purring of a cat.

6. Share poems and compare varied emotions stirred by the literature or image.

\section{RAFT}

This writing strategy places learners in the shoes of a character, encouraging them to write from their perspective as guided by the following:

$$
\begin{aligned}
& R=\text { Role (i.e. Christopher Columbus) } \\
& A=\text { Audience (i.e. people of First Nations) } \\
& F=\text { Format (i.e. a Tweet) } \\
& T=\text { Topic (i.e. Columbus's visit) } .
\end{aligned}
$$

The use of mythical beings for ' $R$ ' in RAFT can encourage learners to look at familiar topics in new ways. For example, an Alien Information Team who investigates Thanksgiving should approach the topic with no preconceived notions, allowing for authentic inquiry into the topic. This activity could be completed using a digital writing application.

\section{Community service projects}

As inspired by an issue explored in a book, learners create a community service project that includes these steps:

- Research the topic.

- Generate ideas that can help to influence the issue.

- Choose an idea that can be transformed into a community service project.

- Develop a plan for the project that includes:

o creating a timeline;

a developing a budget;

a identifying volunteers;

a spreading the word about your project;

o celebrating your hard work. 


\section{Possible other perspectives (POP!)}

This activity encourages learners to advocate for a character from a counterperspective of the presented story. After reading a book, attend to the following:

1. Ask learners about the possible other sides to this story.

2. Generate a list.

3. Select one of the counter stories.

4. As one of the original characters in the book, address the following scenario:

A newspaper has reported the original story of the book. Your assigned character has a different perspective (counterstory). You read this newspaper article and are outraged by the biased reporting and twisted slant of the article. Committed to the full story being told, you write a letter to the editor setting the newspaper straight.

5. Create a bulletin board with all the POP! stories.

6. As an additional step, ask the students to select a letter, reply as the editor and include supporting evidence for their position.

It is innate for educators to explore perspective through literature. By their very nature books offer different views of the world. However, we suggest that the intentional and consistent cultivation of perspective consciousness should be a mainstay of the everyday routine of classrooms. These suggested activities are starting points in seeding this habit of mind. Although the books listed are children's picture books, these books and activities can be used with learners of all ages. More complex chapter books or excerpts from novels can additionally be used alongside these activities.

\section{Final thoughts}

Educators are positioned to empower global citizenship. They can provide opportunities and rich experiences that develop global-minded learners to possess the ideals of acceptance, altruism and empathy. The book collections and accompanying activities shared in this article provide a first step in the lifelong journey of expanding one's perspective beyond one's personal orbit. This article serves as a call for educators to thoughtfully expand their book collections and design curricular learning experiences that actively promote the development of perspective consciousness. The realization that our problems are contextually unique, yet often similar to others around the globe, is a developmentally complex realization. Thoughtfully curated book collections are the catalyst to discovering a panoramic perspective of the world.

\section{Notes on the contributors}

Sheila Baker is Associate Professor in the College of Education School Library and Information Science programme at the University of Houston-Clear Lake. Having taught for over 20 years in public schools, she currently empowers teachers and pre-service school librarian candidates who seek to expand their knowledge of information and digital literacies. In a world where many borders and barriers to worldwide information have been virtually eliminated, she teaches students literacies that are fundamental in nurturing global citizens.

Debby Shulsky is a social studies educator with over 20 years' experience. She currently designs learning experiences for Early Childhood-12 undergraduate teacher candidates, which explore pedagogies that cultivate the essential literacies and habits 
of mind required of critically engaged global citizens. Based in social justice, her body of work illuminates practical classroom strategies that empower young learners to see themselves as agents of change, ready to take critically informed action in their communities and the world at large.

\section{References}

AASL (American Association of School Librarians) (2018) National School Library Standards for Learners, School Librarians, and School Libraries. Chicago: American Library Association.

ALA (American Library Association) (2018) 'Selection criteria'. Online. https://tinyurl.com/y92rgkpq (accessed 23 April 2020).

Alko, S. and Qualls, S. (2015) The Case for Loving: The fight for interracial marriage. New York: Arthur A. Levine Books.

Amnesty International (2015) We Are All Born Free: The Universal Declaration of Human Rights in pictures. London: Frances Lincoln Children's Books.

Atkins, L., Yogi, S. and Houlette, Y. (2017) Fred Korematsu Speaks Up (Fighting for Justice). Berkeley: Heyday.

Banks, J.A. (2008) 'Diversity, group identity, and citizenship education in a global age'. Educational Researcher, 37 (3), 129-39.

Barroux (2016) Welcome. New York: Little Bee Books.

Bell, D., Jean-Sigur, R.E. and Kim, Y.A. (2015) 'Going global in early childhood education'. Childhood Education, 91 (2), 90-100.

Bista, K. and Saleh, A. (2014) 'Assessing the need for graduate global education programs in the United States'. Journal of International and Global Studies, 5 (2), 19-39.

Boelts, M. and Jones, N.Z. (2009) Those Shoes. Somerville, MA: Candlewick Press.

Bonsper, P. and Rink, D. (2015) The Problem of the Hot World. North Charleston, SC: CreateSpace.

Bosniak, L. (2001) 'Denationalizing citizenship'. In Aleinikoff, T.A. and Klusmeyer, D. (eds) Citizenship Today: Global perspectives and practices. Washington, DC: Brookings Institution Press, 237-52.

Brandt, L. and Vogel, V. (2014) Maddi's Fridge. New York: Flashlight Press.

Britt, P., Qualls, S. and Alko, S. (2017) Why Am I Me? New York: Scholastic Press.

Brown, M. and Palacios, S. (2011) Marisol McDonald Doesn't Match. San Francisco: Children's Book Press.

Brown, M. and Parra, J. (2011) Waiting for the Biblioburro. Berkeley: Tricycle Press.

Buitrago, J. and Yockteng, R. (2015) Two White Rabbits. Toronto: Groundwood Books.

Bunting, E. and Himler, R. (1993) Fly Away Home. New York: Clarion Books.

Bunting, E. and Lewin, T. (2006) One Green Apple. New York: Clarion Books.

Burnouf, L. (2004) 'Global awareness and perspectives in global education'. Canadian Social Studies, 38 (3), 1-12.

Burns Knight, M., Melnicove, M. and Sibley O’Brien, A. (2002) Africa is Not a Country. Minneapolis: Millbrook Press.

Button, L. and Howells, T. (2013) Willow Finds a Way. Toronto: Kids Can Press.

Calì, D. and Mourrain, S. (2017) The Tiny Tale of Little Pea. Toronto: Kids Can Press.

Cardaciotto, L., Herbert, J.D., Forman, E.M., Moitra, E. and Farrow, V. (2008) 'The assessment of present-moment awareness and acceptance: The Philadelphia Mindfulness Scale'. Assessment, 15 (2), 204-23.

Caruana, V. (2014) 'Re-thinking global citizenship in higher education: From cosmopolitanism and international mobility to cosmopolitanisation, resilience and resilient thinking'. Higher Education Quarterly, 68 (1), 85-104.

Castle, C. (2014) 'Global citizenship education: Basic approaches and understandings'. Presentation given at the Asia-Pacific Regional Education Conference, Bangkok, Thailand, 6-8 August 2014.

Cho, T.M. and Song, K.J. (2018) Rice from Heaven: The secret mission to feed North Koreans. New York: Little Bee Books.

Churnin, N. and Popovici, D. (2017) Manjhi Moves a Mountain. Berkeley: Creston Books.

Churnin, N. and Rey Sanchez, J. (2018) Irving Berlin: The immigrant boy who made America sing. Berkeley: Creston Books.

Claire, C. and Leng, Q. (2017) Shelter. Toronto: Kids Can Press.

Clifford, V. and Montgomery, C. (2014) 'Challenging conceptions of Western higher education and promoting graduates as global citizens'. Higher Education Quarterly, 68 (1), 28-45. 
Danticat, E. and Staub, L. (2015) Mama's Nightingale: A story of immigration and separation. New York: Dial Books for Young Readers.

Davies, N. and Carlin, L. (2017) King of the Sky. Somerville, MA: Candlewick Press.

Davies, N. and Cobb, R. (2018) The Day War Came. Somerville, MA: Candlewick Press.

Daywalt, D. and Jeffers, O. (2013) The Day the Crayons Quit. New York: Philomel Books.

De Arias, P. and Borràs, L. (2018) Marwan's Journey. Hong Kong: Minedition.

Deedy, C.A. and Gonzalez, T. (2016) 14 Cows for America. Atlanta: Peachtree.

Del Rizzo, S. (2017) My Beautiful Birds. Toronto: Pajama Press.

Diller, K., Lowe, J. and Binny, T. (2016) Hello, My Name is Octicorn. New York: Balzer and Bray.

Dr Seuss (1984) The Butter Battle Book. New York: Random House.

Eggers, D. and Harris, S. (2017) Her Right Foot. San Francisco: Chronicle Books.

Eidoo, S., Ingram, L.-A., MacDonald, A., Nabavi, M., Pashby, K. and Stille, S. (2011) '"Through the kaleidoscope": Intersections between theoretical perspectives and classroom implications in critical global citizenship education'. Canadian Journal of Education, 34 (4), 59-84.

Elliott, R. (2014) Just Because. Oxford: Lion Children's Books.

Engle, M. and López, R. (2015) Drum Dream Girl: How one girl's courage changed music. Boston: Houghton Mifflin Harcourt.

Erskine, K. and Palmer, C. (2017) Mama Africa! How Miriam Makeba spread hope with her song. New York: Farrar Straus Giroux.

Fleischman, P. and Ibatouline, B. (2016) The Matchbox Diary. Somerville, MA: Candlewick Press.

Fox, M. and Staub, L. (2006) Whoever You Are. Orlando: Voyager Books.

Fox, M. and Wilton, N. (2000) Feathers and Fools. San Diego: Voyager Books.

Frier, R., Fronty, A. and Cormier, J. (2017) Malala: Activist for girls' education. Watertown, MA: Charlesbridge.

Fullerton, A. and Patkau, K. (2013) A Good Trade. Toronto: Pajama Press.

Gaynor, K. and Sweeney, C. (2009) A Friend like Simon. Dublin: Special Stories Publishing.

Gerstein, M. (2017) The Boy and the Whale. New York: Roaring Brook Press.

Gonzalez, X. and Garcia, A.M. (2017) All Around Us. El Paso, TX: Cinco Puntos Press.

Gunning, M. and Pedlar, E. (2013) A Shelter in Our Car. New York: Lee and Low Books.

Hall, M. (2015) Red: A crayon's story. New York: Greenwillow Books.

Hanvey, R.G. (1982) 'An attainable global perspective'. Theory into Practice, 21 (3), 162-7.

Holub, J. and Roode, D. (2017) This Little Trailblazer: A girl power primer. New York: Simon and Schuster.

Holwitz, P. (2005) Scribbleville. New York: Philomel Books.

Hood, S. and Comport, S.W. (2016) Ada's Violin: The story of the Recycled Orchestra of Paraguay. New York: Simon and Schuster.

hooks, b. and Raschka, C. (2017) Skin Again. New York: Jump at the Sun.

Isabella, J. and Shin, S. (2015) The Red Bicycle: The extraordinary story of one ordinary bicycle. Toronto: Kids Can Press.

ISTE (International Society for Technology in Education) (2020) 'ISTE Standards for Students'. Online. www.iste.org/standards/for-students (accessed 23 April 2020).

Kamkwamba, W., Mealer, B. and Zunon, E. (2012) The Boy Who Harnessed the Wind. New York: Dial Books for Young Readers.

Karlberg, M. (2008) 'Discourse, identity, and global citizenship'. Peace Review: A Journal of Social Justice, 20 (3), 310-20.

Kavelaris, A. (2016) Bloom with Mi: "Using our gifts to give". Bloom-Prints Studio.

Kobald, I. and Blackwood, F. (2015) My Two Blankets. Boston: Houghton Mifflin Harcourt.

Krull, K. and Morales, Y. (2003) Harvesting Hope: The story of Cesar Chavez. San Diego: Harcourt.

Lawlor, L. and Beingessner, L. (2012) Rachel Carson and Her Book that Changed the World. New York: Holiday House.

Lee Shetterly, M., Conkling, W. and Freeman, L. (2018) Hidden Figures: The true story of four black women and the space race. New York: HarperCollins.

Lemniscates (2012) Silence. Washington, DC: Magination Press.

Lennon, J., Davis, B. and Coh, S. (2018) Heal the Earth. New York: Sky Pony Press.

Levinson, C. and Brantley-Newton, V. (2017) The Youngest Marcher: The story of Audrey Faye Hendricks, a young civil rights activist. New York: Atheneum Books for Young Readers.

Logan, A. and Wendt, T. (2013) A Girl with a Cape: The true story about the superhero in all of us. Joliet, IL: Full Heart Publishing. 
Maclear, K. and Arsenault, I. (2017) Spork. Toronto: Kids Can Press.

Mantchev, L. and Yoo, T. (2015) Strictly No Elephants. New York: Simon and Schuster.

Markel, M. and Sweet, M. (2013) Brave Girl: Clara and the Shirtwaist Makers' Strike of 1909. New York: Balzer and Bray.

Mayeno, L., Liu-Trujillo, R. and Mlawer, T. (2016) One of a Kind, Like Me = Único como yo. Oakland, CA: Blood Orange Press.

McBrier, P. and Lohstoeter, L. (2004) Beatrice's Goat. New York: Aladdin.

McCutcheon, J. and Caldwell, K. (2017) Flowers for Sarajevo. Atlanta: Peachtree.

McGhee, H.M. and Lemaître, P. (2017) Come with Me. New York: G.P. Putnam's Sons.

Mobin-Uddin, A. and Kiwak, B. (2005) My Name is Bilal. Honesdale, PA: Boyds Mills Press.

Munson, D. and Calahan King, T. (2000) Enemy Pie. San Francisco: Chronicle Books.

Myers, J.P. (2016) 'Charting a democratic course for global citizenship education: Research directions and current challenges'. Education Policy Analysis Archives, 24 (55), 1-16.

Nagara, I. (2013) A is for Activist. New York: Seven Stories Press.

NCSS (National Council for the Social Studies) (2017) 'National Standards for the Preparation of Social Studies Teachers'. Online. www.socialstudies.org/standards/teacherstandards (accessed 15 September 2018).

Nelson, K. (2015) If You Plant a Seed. New York: Balzer and Bray.

Nuño, F., Celej, Z. and Brokenbow, J. (2017) The Map of Good Memories. Madrid: Cuento de Luz.

Otoshi, K. (2010) Zero. Novato, CA: KO Kids Books.

Otoshi, K. (2017) Draw the Line. New York: Roaring Brook Press.

Palacio, R.J. (2017) We're All Wonders. New York: Alfred A. Knopf.

P21 (Partnership for 21st Century Learning) (2014) Framework for State Action on Global Education. Online. https://tinyurl.com/y7jl2y3b (accessed 30 April 2020).

Parr, T. (2010) The Earth Book. New York: Little, Brown Books for Young Readers.

Parton, D. and Boynton Hughes, B. (2016) Coat of Many Colors. New York: Grosset and Dunlap.

Paul, M. (2015). One Plastic Bag: Isatou Ceesay and the recycling women of the Gambia. Minneapolis, MN: Millbrook Press.

Petren, L. and Russita, T. (2018) Lulu and Lainey... at the Farm. North Charleston, SC: CreateSpace.

Phi, B. and Bui, T. (2017) A Different Pond. North Mankato, MN: Capstone.

Prévot, F. and Fronty, A. (2017) Wangari Maathai: The woman who planted millions of trees. Watertown, MA: Charlesbridge.

Reeves Sturgis, B. and Lee, J.-S. (2017) Still a Family: A story about homelessness. Chicago: Albert Whitman and Company.

Reynolds, A. and Davies, M. (2015) Nerdy Birdy. New York: Roaring Brook Press.

Robbins, D. and Zhang, N. (2016) Miss Paul and the President: The creative campaign for women's right to vote. New York: Knopf Books for Young Readers.

Roberts, C. and Kai, H. (2017) Refugees and Migrants (Children in our World). Hauppauge, NY: Barron's.

Rochman, H. (1993) 'Against borders'. Journal of Youth Services in Libraries, 6 (4), 420-3.

Roth, S.L. and Trumbore, C. (2013) Parrots over Puerto Rico. New York: Lee and Low Books.

Rothstein, D. and Santana, L. (2011) Make Just One Change: Teach students to ask their own questions. Cambridge, MA: Harvard Education Press.

Rumford, J. (2010) Rain School. Boston: Houghton Mifflin Books for Children.

Ruurs, M., Badr, N.A. and Raheem, F. (2016) Stepping Stones: A refugee family's journey. Custer, WA: Orca Book Publishers.

Sanders, R. and Salerno, S. (2018) Pride: The story of Harvey Milk and the rainbow flag. New York: Random House.

Sanna, F. (2016) The Journey. London: Flying Eye Books.

Say, A. (2017) Silent Days, Silent Dreams. New York: Arthur A. Levine Books.

Scott Belt, A.A. (2016) 'Does Global Citizenship Education Predict Identification with all Humanity?'. EdD thesis, Western Kentucky University.

Shapiro, J.H. and Brantley-Newton, V. (2015) Magic Trash: A story of Tyree Guyton and his art. Watertown, MA: Charlesbridge.

Shulsky, D.D., Baker, S.F., Chvala, T. and Willis, J.M. (2017) 'Cultivating layered literacies: Developing the global child to become tomorrow's global citizen'. International Journal of Development Education and Global Learning, 9 (1), 49-63. 
Shulsky, D. and Hendrix, E.Y. (2016) 'Rooting the literacies of citizenship: Ideas that integrate social studies and language arts in the cultivation of a new global mindset'. In Crowe, A.R. and Cuenca, A. (eds) Rethinking Social Studies Teacher Education in the Twenty-First Century. Cham: Springer, 101-19.

Sibley O'Brien, A. (2015) I'm New Here. Watertown, MA: Charlesbridge.

Sileo, F.J. and Zivoin, J. (2017) A World of Pausabilities: An exercise in mindfulness. Washington, DC: Magination Press.

Simon, R., Simon, T. and Siegel, M. (2015) Oskar and the Eight Blessings. New York: Roaring Brook Press.

Smith Milway, K. and Daigneault, S. (2010) The Good Garden: How one family went from hunger to having enough. Toronto: Kids Can Press.

Smith Milway, K. and Evans, S.W. (2017) The Banana-Leaf Ball: How play can change the world. Toronto: Kids Can Press.

Smith Milway, K. and Fernandes, E. (2008) One Hen: How one small loan made a big difference. Toronto: Kids Can Press.

Smith Milway, K. and Fernandes, E. (2012) Mimi's Village: And how basic health care transformed it. Toronto: Kids Can Press.

Spilsbury, L. and Kai, H. (2017) Poverty and Hunger. Hauppauge, NY: Barron's.

Spilsbury, L. and Kai, H. (2018a) Global Conflict. Hauppauge, NY: Barron's.

Spilsbury, L. and Kai, H. (2018b) Racism and Intolerance. Hauppauge, NY: Barron's.

Thompson, L. and Hale, C. (2012) The Forgiveness Garden. New York: Feiwel and Friends.

Thompson, L.A. and Qualls, S. (2015) Emmanuel's Dream: The true story of Emmanuel Ofosu Yeboah. New York: Schwartz and Wade Books.

Tonatiuh, D. (2014) Separate is Never Equal: Sylvia Mendez and her family's fight for desegregation. New York: Abrams Books for Young Readers.

Tyler, M. and Csicsko, D.L. (2005) The Skin You Live In. Chicago: Chicago Children's Museum.

UNESCO (United Nations Educational, Scientific and Cultural Organization) (2019) 'Global citizenship education'. Online. https://en.unesco.org/themes/gced (accessed 23 April 2020).

Verde, S., Badiel, G. and Reynolds, P.H. (2016) The Water Princess. New York: G.P. Putnam's Sons.

Verde, S. and Parra, J. (2018) Hey, Wall: A story of art and community. New York: Simon and Schuster Books for Young Readers.

Whelan, G. and Sylvada, P. (2007) Yatandou. Chelsea, MI: Sleeping Bear Press.

Wiggins, G.P. and McTighe, J. (2005) Understanding by Design. 2nd ed. Alexandria, VA: Association for Supervision and Curriculum Development.

Williams, K.L., Mohammed, K. and Chayka, D. (2007) Four Feet, Two Sandals. Grand Rapids, MI: Eerdmans Books for Young Readers.

Williams, L.E. and Orback, C. (2017) The Can Man. New York: Lee and Low Books.

Winter, J. and Innerst, S. (2017) Ruth Bader Ginsburg: The case of R.B.G. vs Inequality. New York: Abrams Books for Young Readers.

Wyeth, S.D. and Ibatoulline, B. (2013) The Granddaughter Necklace. New York: Arthur A. Levine Books.

Young, R. and Ottley, M. (2016) Teacup. New York: Dial Books for Young Readers.

Zietlow Miller, P. and Hill, J. (2018) Be Kind. New York: Roaring Brook Press. 